\title{
Understanding the robotic restaurant experience: a multiple case study
}

Faruk Seyitoğlu and Stanislav Ivanov

\begin{abstract}
Purpose - The purpose of this study is to investigate the robotic restaurant experience of travellers around the world and understand the components of robotic restaurant experience.

Design/methodology/approach - Travellers who had experienced a robotic restaurant were purposefully selected as a sample group for the study. As the robotic restaurants are limited around the world, multiple case study method has been chosen to gather richer data. A user-generated content technique which is a form of qualitative case study method has been benefited to gather data from travellers' reviews.

Findings - The results reveal a model of components of robotic restaurant experience that include six main themes: attraction for kids, robotic system, memorable experience, ambience related attributes, food related attributes (economic value and gastronomic aspects) and deficiencies (in robotic system, in ambience related attributes and in food related attributes).

Originality/value - This paper is one of the first to investigate the robotic restaurant experience of travellers around the world. Moreover, it contributes to the research on restaurant experience and offers a model of components of the robotic restaurant experience.
\end{abstract}

Keywords Multiple case study, Service robots, Online reviews, Thematic content analysis, Restaurant experience, Robotic restaurant

Paper type Research paper

\section{Introduction}

Customer experience is defined as the overall experience which is formed through the interaction with service providers (Yrjölä et al., 2019). The literature stresses that experiences may influence customers' decisions and behaviours (Helkkula, 2011; Gentile et al., 2007); therefore, understanding the experience of customers is beneficial for managers, entrepreneurs, and destination planners (Yrjölä et al., 2019).

Dining is an important integral element of the travel experience and it is one of the top five tourist activities while travelling (Vu et al., 2019). Furthermore, travellers spend a significant amount of their overall budget on food and beverages (Seyitoğlu and Ivanov, 2020b; Coughlan and Saayman, 2018). In this respect, restaurants are playing an important supportive role for travellers through offering not only food and beverages but also enjoyable and memorable experiences (Karamustafa and Ülker, 2020) which customers may easily share on social media platforms (Nemeschansky, 2020). The literature indicates that the dining experience of customers has a close relationship with restaurant attributes which are affecting customers' satisfaction and future behavioural intentions (Kwun and Oh, 2006; Chen and $\mathrm{Hu}, 2010)$. It is shaped by various factors such as restaurant's food-related attributes, service quality, the staff, ambience related attributes, location, and the presence of other customers (Yrjölä et al., 2019; Zhang et al., 2019).

Recently, the tourism and hospitality industry has been affected significantly by the growth of information communication technologies (Buhalis and Law, 2008). The use of technology
Faruk Seyitoğlu is based at Faculty of Tourism, T.C. Mardin Artuklu University, Mardin, Turkey. Stanislav Ivanov is based at Varna University of Management, Varna, Bulgaria. 
is seen beneficial in terms of competitive advantage, efficiency and creating a unique hospitality experience (Yu and Ngan, 2019). Defined as "actuated mechanism programmable in two or more axes with a degree of autonomy, moving within its environment, to perform intended tasks" (International Organization for Standardization, 2012), a robot is not a peculiarity in hospitality businesses any more. Currently, hospitality companies start to adopt service robots for various activities such as housekeeping attendants, bellboys, guides, hosts, porters, cooking staff, room servers, waiters, etc. (Ivanov and Webster, 2019c; Ivanov et al., 2017; Lu et al., 2019; Drexler and Lapré, 2019). The COVID-19 pandemic is expected to stimulate robot adoption in the future even further for cleaning, disinfection and provision of physically distant services (Seyitoğlu and Ivanov, 2020a; Zeng et al., 2020). Therefore, naturally, the number of studies on service robots in hospitality and tourism industry is growing (Chan and Tung, 2019; Choi et al., 2019; Ivanov et al., 2019; Li et al., 2019; Lu et al., 2019; Murphy et al., 2019; Murphy et al., 2017; Tung and Law, 2017; Tung and Au, 2018; Yu and Ngan, 2019; Zhong et al., 2020).

On the other hand, there is an extensive literature related to restaurant experience (Andersson and Mossberg, 2004; Jeong and Jang, 2011; Jin et al., 2012; Kim and Jang, 2019; Pantelidis, 2010; Ryu and Han, 2011). However, despite the growing research on service robots in a restaurant context (Berezina et al., 2019; Eksiri and Kimura, 2015; Lee et al., 2018; Mathath and Fernando, 2017; Tuomi et al., 2019), there is a lack research on the robotic restaurant experience in the current literature. In the restaurant dining experience, there is human-to-human contact between employees and customers. On the other hand, in the robotic restaurants, the frontline employees (waiters) are not human anymore. In this respect, the context of the robotic restaurant experience completely differs from the restaurant dining experience. Thus, the restaurants providing robotic services may enable different aspects of experiences to their customers. This makes it necessary to learn about visitor experience in robotic restaurants which will be helpful to guide restaurant businesses to increase the quality of experiences they provide to their customers. This study aims to partially fill in this research gap.

In light of the above discussion, this paper aims to investigate the robotic restaurant experience of consumers. In particular, the paper delves into how customers perceive the use of robotics in restaurants and how robotics contributes to their dining experience. The rest of the paper is organised as follows. Section 2 provides a focused review of the literature on customer experiences in robotic restaurants. Section 3 explains the methodology. Section 4 presents and discusses the findings, while Section 5 elaborates on paper's theoretical contribution, managerial implications, limitations and future research directions and concludes the paper.

\section{Literature review}

\subsection{Restaurant dining experience}

Food has always been a necessary part of travel and the culinary experience provided in a destination attracts tourists (Cohen and Avieli, 2004; Hu et al., 2009; Seyitoğlu, 2020). Restaurants allow customers to learn about different cultures via food from various regions which enable customers to have authentic and unique experiences (Ingerson and Kim, 2016). Restaurant dining experience is a multidimensional concept, that has various attributes that are determining the perception of customers (Yrjölä et al., 2019), namely, service staff, cleanliness, location, décor, environment, atmosphere, food taste and menu (Andersson and Mossberg, 2004; Ryu and Jang, 2008; Heung and Gu, 2012). It is possible to group these attributes under three main categories such as ambience, food, and servicerelated attributes which are accepted as indicators of the quality of restaurant experience (Ryu et al., 2012). 
Ambience-related attributes refer to the physical aspects of the restaurants such as décor and interior, music, cleanliness, air quality, exterior view of employees, signs, facility aesthetics, comfort, temperature, noise, view, type of lighting and dining equipment (Heung and Gu, 2012; Jin et al., 2015; Kim and Moon, 2009; Ryu and Jang, 2008; Ryu et al., 2012). The quality of ambience-related attributes may be defined as customers' evaluations about the performance of the restaurant's physical environment (Yrjölä et al., 2019). It is stressed in the literature that from the ambience-related attributes acoustic conditions, lighting, appropriate temperature, cleanliness, and décor are the most significant components determining the dining experience (Jin et al., 2015). Therefore, creating and providing a dining area that offers a high standard of ambience to customers is vital for restaurant businesses (Zhang et al., 2019).

The food-related attributes include the dimensions of food such as taste, freshness, menu content, food variety, portion sizes, and nutrition value. Further, the evaluation of customers related to these issues determines the food quality in restaurants (Yrjölä et al., 2019), which is considered as one of the most significant components of the dining experience (Zhang et al., 2019). As the third main component of the restaurant dining experience, servicerelated attributes include service speed, service failures and staff attitudes and abilities. These attributes influence the level of service quality in restaurants (Yrjölä et al., 2019). Service quality has been defined as the judgment of customers towards the excellence or superiority of the service (Ribeiro and Prayag, 2019).

Among these attributes, the food-related attributes are considered the most important factors in dining experiences (Oh et al., 2019), because customers pay significant attention to food presentation, taste, freshness, healthiness, portion sizes, menu variety, etc. (Namkung and Jang, 2007); however, the other attributes contribute to the quality of the restaurant dining experience as well (Longart et al., 2018). For example, Choi and Zhao (2010) point out that cleanliness, service, ambiance, price, and health issues are indicators of the restaurant experience of customers.

In summary, according to the related literature, many factors such as food quality, service, price, cleanliness, atmosphere, menu content, and health issues are shaping the restaurant experience (Choi and Zhao, 2010; Vu et al., 2019). Besides, service quality, comfort, atmosphere, décor and location are vital elements in the creation of memorable restaurant experiences (Nemeschansky, 2020). Furthermore, the perceptions of customers about the restaurant attributes are accepted as one of the most significant concepts to understand the behaviour of customers (Ingerson and Kim, 2016). Therefore, knowing the effective restaurant attributes may help managers to develop more specific strategies to address customers' expectations (Vu et al., 2019). Additionally, being aware of the components of the dining experience is seen as vital for the success of restaurants (Zhang et al., 2019).

\subsection{Robots in restaurant dining experience}

The technological development has led the tourism and hospitality services to a future economy in which artificial intelligence and robots might be used at all stages of the service process (Kazandzhieva and Filipova, 2019). As experiencing service robots in daily life or hotels is a unique and new experience, customers may then want to interact with robots (Choi et al., 2019) because they may feel more comfortable with robotic service and have a positive perception of robots (Kazandzhieva and Filipova, 2019). However, although robotic technology is developing, people are still unfamiliar with robotic devices, thus interacting with them does not happen frequently in their life. This makes the experience extraordinary and has the potential to enhance the satisfaction level of customers (Choi et al., 2019). Additionally, as robots are considered novel, extraordinary, and unique, guests may have memorable experiences when they encounter robots in various tasks in a service environment (Sthapit, 2017), including in hospitality (Tung and Law, 2017; Tung and Au, 2018) and restaurant context. 
Due to advances in artificial intelligence and robotics (Miller and Miller, 2017; Russell and Norvig, 2016), many tasks in a restaurant are possible to automate (Xiao and Kumar, 2019). Depending on their technological features, restaurant robots can serve, cook, take dirty dishes, host guests, dance, communicate with customers, etc. (Berezina et al., 2019). Robot chefs prepare noodles, burgers, coffee, sushi, grill and mix drinks (Ivanov et al., 2017). However, prior studies have indicated that not all tasks in a restaurant are considered by customers as appropriate for robotization. For example, based on a global sample of over 1,000 respondents, Ivanov and Webster (2019b) found that customers considered the most suitable application of robots in a restaurant context the following activities: cleaning the table, providing information about the menu and taking the orders; while serving the food and, especially, cooking food were considered as least appropriate for robotization. Moreover, the perceived appropriateness of robot application in a restaurant context influenced positively respondents' intention to use service robots (Ivanov and Webster, 2019a). Therefore, although the literature says that service robots may be used for creating experiences in hospitality (Tung and Law, 2017; Tung and Au, 2018), some activities are not acceptable for robotization and may lead to a potential loss of human contact (Tussyadiah, 2020) and customers' dissatisfaction with the dining experience.

\section{Methodology}

This study was designed to answer the question about the kind of experiences that robotic restaurants offer to their guests and to identify the components of the robotic restaurant experience. That is why inductive approach was chosen as a research approach, while travellers who had experienced a robotic restaurant around the world were purposefully selected as a sample group for the study. As robotic restaurants are limited around the world, multiple case studies have been chosen as a research strategy to gather richer data from more restaurants around the world. Case studies are considered as an appropriate research strategy to analyse social phenomena (Creswell, 2009). As travellers consult widely with user-generated content (UGC) to help them make travel decisions (Yoo and Gretzel, 2011), UGC is accepted as a significant source of information for travellers and tourism firms (Narangajavana et al., 2019). Lately, travellers are mostly relying on UGC platforms and websites, to gather the information that is needed to make travel decisions (Assaker, 2019). Thus, the present study adopted the analysis of online reviews of robotic restaurants as an analytical technique.

On the other hand, the restaurant reviews are considered as valuable data resources to explore effectively and comprehensively the dining experiences of travellers ( $\mathrm{Vu}$ et al., 2019). That is why for the present qualitative case study, the authors focused on the reviews posted by customers who had experienced robotic restaurants. The data were gathered from tripadvisor.com which is one of the most popular review websites (Jeacle and Carter, 2011). Moreover, previous studies on robots in tourism have analysed customer reviews as well (Bhimasta and Kuo, 2019; Yu, 2020).

The data of this study were gathered between the 18th and 29th of November 2019 from travellers' online reviews in English $(n=582)$ posted between June 2012 and November 2019 , describing experiences they had from 13 robotic restaurants. Three of the restaurants operated in India, three in Thailand, two in Malaysia, two in the USA, and the rest of them operated in Nepal, Canada, and Sweden. Table 1 presents the characteristics of restaurants included in the analysis. The data were collected from reviews starting from the beginning of November 2019 working back to older reviews. As it was decided that the themes and sub-themes were clear and theoretical saturation had been reached (Glaser and Strauss, 1967), the sampling was stopped after the 582nd review.

The comments were analysed through thematic content analysis which is the technique often benefited to investigate the textual data to shape structures and categories 
Table 1 Restaurants included in the analysis

\begin{tabular}{|c|c|c|c|c|}
\hline No. of restaurants & Location & Cuisine type & No. of reviews & Period of the reviews \\
\hline 1 & Toronto, Canada & Japanese cuisine & 31 & 03.09.2018-20.11.2019 \\
\hline 2 & Coimbatore, India & Chinese and Hindu cuisines & 11 & 29.09.2018-18.11.2019 \\
\hline 3 & Chennai, India & Chinese and Thai cuisines & 15 & $06.01 .2018-05.10 .2019$ \\
\hline 4 & Jaipur, India & Mexican, Indian and Asian cuisines & 24 & 01.08.2018-22.10.2019 \\
\hline 5 & Ipoh, Malaysia & Chinese cuisine & 29 & 12.09.2016-12.11.2019 \\
\hline 6 & Kuala Lumpur, Malaysia & Cantonese and Malaysian cuisines & 310 & 24.10.2018-29.11.2019 \\
\hline 7 & Kathmandu, Nepal & Indian and Nepalese cuisines & 17 & 11.08.2019-23.08.2019 \\
\hline 8 & Bang Lamung, Thailand & Thai cuisine & 4 & 08.03.2015-28.06.2018 \\
\hline 9 & Bangkok, Thailand & Japanese cuisine & 77 & 09.08.2012-30.09.2019 \\
\hline 10 & Pattaya, Thailand & Chinese and Japanese cuisines & 2 & 05.01.2019-03.08.2019 \\
\hline 11 & Brookhaven, Georgia, USA & Italian and American cuisines & 5 & $18.02 .2019-15.08 .2019$ \\
\hline 12 & Boston, Massachusetts, USA & Indian and Latin cuisines & 46 & 07.05.2018-14.10.2019 \\
\hline 13 & Lidköping, Sweden & Indian and Thai cuisines & 11 & 29.04.2016-13.10.2018 \\
\hline
\end{tabular}

related to phenomenon (Stepchenkova et al., 2009). At the initial stage of the analysis, after choosing the unit of analysis, the narratives of travellers were collected from TripAdvisor and transferred to a Word file. An inductive content analysis (Thomas, 2006) of the reviews was simultaneously performed by three independent human coders who have experience in qualitative data analysis and methods to determine themes and sub-themes. For example, the statements such as "the kids wanted to see the robots", "kids really enjoyed when they saw Robo", "my son loves robots", "the robot was fun for the kids", "kids seem excited when the robot serve", "great place to bring the kids" were coded under the theme of "attraction for kids". After coders' agreement of emerged categories and sub-categories, the results have been reported and findings are written (Elo et al., 2014).

\section{Findings}

The data analysis revealed that the travellers' comments could be classified into six major categories: "attraction for kids," "robotic system," "memorable experience," "ambience related attributes," "food related attributes (economic value and gastronomic aspects)" and deficiencies (in robotic system, in ambience related attributes and in food related attributes).

\subsection{Attraction for kids}

Most of the travellers assert that robotic restaurants are attractive places for kids. As parents expressed, children are the main motivation sources for them to visit robotic restaurants. It is clear from the statements of travellers that kids wanted to see robots, they really enjoyed them, had fun, took pictures with robots, etc. In particular, customers commented that:

[...].The key attraction is the dancing robot serving us. [...] The kids were extremely thrilled and curious by the robot [...] [C201].

We came here merely for the robotic waitresses [...]. The kids would love the robots and the environment [C94].

A great number of restaurant customers mentioned that robots had the potential to distract children which enables a better dining experience for parents. For instance, customer 172 [C172] says that: 
[...] if you have kids, this appears to be a great place to bring children as they will be distracted by the robots going around the restaurant delivering food orders and taking guests to their table $[\ldots][$ C172].

Several other customers indicate that robots were entertaining and keep kids excited because robots are not only serving but also dancing. For example, C236 hints that "It's fun to watch the robots serve and do the dance. Quite entertaining and keeps kids excited and busy [...]" [C236]. Some additional comments which show that robots are fun for kids are given below:

Admittedly this has become more of a tourist attraction, than a serious place to eat! But it's great fun to see the robot deliver your food and the food itself is what you would expect from a (Thai) Japanese restauran $t[. .$.$] a fun experience for the kids rather than a place to sample Japanese$ cuisine [...]. They even dance to Gangnam Style! [C235].

The kids enjoyed the meal here, just because of the robo [...][...]. However, the robot service will make up for it. When we were there the robot did a Gangnam style dance, which, was entertaining. Try to spread out your orders to get more attention from the robot [... . [C260]

These findings confirm findings in prior studies that service robots are a strong pull motivation for guests as they provide enjoyment for their children (Choi et al., 2019). Considering that children have a significant impact on decision-making process (Kim et al., 2010; Rhoden et al., 2016), including on the decision to dine out and on selecting a restaurant (Labrecque and Ricard, 2001; Chen et al., 2016), robot restaurants need to pay special attention on how their robots are perceived and accepted by children.

\subsection{Robotic system}

The results demonstrate that travellers explained the working system in robotic restaurants. According to the posts of a significant number of travellers, the restaurants providing robotic dining experience use robot servers and benefit from tablets or touch screen tables with menus for ordering food and beverages. Further, the touch screen tables may also be used as a television or to watch the cooking process in the kitchen. For instance, one of the customers (C44) indicates that "Imagine ordering food as soon as you choose [...] from a KIOSK table [...] and getting served by a robot".

On the other hand, when it comes to robot servers, some customers shared that robots in restaurants have names and serve as hosts/hostesses who take guests to their tables.

[...] Long story short, but make sure you have one of the robot servers lead you to your table! It's a cute experience [...]. On our tables were iPads for ordering the food [...] It turns out there are two types of robots at Robo Sushi. One type is the small attendant with a cute face made to act like hosts/hostesses to guide you to your table while the second type are faceless with shelves to deliver food [...]. When this second type of robot brought some of our orders to our table, we took the plates of food from the robot ourselves. Then an actual human server came around and pressed a button on the robot to send it back to the kitchen. It was pretty cool to see the robot automatically programmed to come to our table to deliver the food [...] [C174].

One of the restaurants included in the sample was a fast-food restaurant operating in the USA. As customers explain, the meals get cooked by robots then humans add some vegetables and dressing. The concept, named "robotic cooking," is fast food and only several items can be made via this method. Some of the relevant comments of customers include:

Wow! This place is great! You choose a meal, enter your info and pay and up pops your name welcoming you to the restaurant. A few seconds later a pan magically appears cooking the meat for your bowl meal, you can watch the show! Your meal gets cooked then the humans add some 
vegetables and dressing and shazaammm![...]. What a great idea! Congratulations to whomever put this one together [...] [C124].

These findings contradict the results of Ivanov and Webster (2019b) who found that cooking food was not considered as acceptable task for robotization in restaurants. The reasons might be due to the fact that the reviews in this research were written by people who have actually experienced the robotic service, while the sample of Ivanov and Webster (2019b) included respondents who had not necessarily experienced a robot-delivered service.

\subsection{Memorable Experience}

The memories of people are believed to be the most reliable source to guide their postpurchasing behaviours and decisions (Zhang et al., 2018). In addition, if they remain in the memory of people, experiences are seen as valuable (Di-Clemente et al., 2019). Moreover, extraordinary, unusual, new and unique events or experiences are better remembered than ordinary ones (Sthapit, 2017).

Unique Dining Experience [...]. Took my mum and sister here to provide a unique dining experience [...]. All in all, a pleasant dining experience [...] [C88].

[...] This is probably more fun and memorable than any of the best restaurants in Boston [...] Might this be the future of cooking? [C142]

[...] the robot system really made the experience unique [C313]

The findings demonstrate that the travellers experiencing robotic restaurants generally found the experience new and unique which is considered as components of memorable experience (Kim et al., 2012). The memorable experience perception of travellers may affect the revisit and positive word of mouth intention of them (Ali et al., 2016). Therefore, a memorable restaurant experience may be accepted as motivation to try the experience again (Antón et al., 2019).

\subsection{Ambience related attributes}

Ambience related attributes refer to the components such as atmosphere, décor, cleanliness, environment, comfort level, music and a sound level of robotic restaurants that customers had experienced.

[... ] were indeed impressed with the decor \& set-up of this restaurant [. . . [C499].

Atmosphere: they play great music, there are tables and two counters to eat (with chairs), just a cool new little spot![ ...] [C156].

Ambience is comfortable and decent. With spacious seating area this is one good location for spending good time with your family and loved ones! [C59]

Ambience-related attributes are some of the indicators of the quality of restaurant experience (Ryu and Han, 2010; Ribeiro and Prayag, 2019); they have also a significant role in creating a memorable dining experience and influencing customer satisfaction of restaurants (Zhang et al., 2019). According to the research findings, customers' words such as "lovely ambience," "nice ambience," and "good ambience" show that they generally liked the ambience of robotic restaurants.

\subsection{Food related attributes}

Food-related attributes in customers' comments referred to economic aspects of food (such as the price fairness, the comparison of portion size and price, and value for money) and gastronomic aspects of food (e.g. taste, harmony, freshness and menu diversity). 
4.5.1 Economic value. The value for the money that consumers perceive is dependent on the balance between price and quality (Kim et al., 2019), often referred to as the economic value of the product (Yrjölä et al., 2019). On the other hand, the price perception of consumers may affect their satisfaction and behaviours in the restaurant experience. Therefore, the prices of food in restaurants should be in line with the balance of quality (Jin et al., 2012). The reasonable prices have been accepted as a significant component of restaurant experience for visitors (Karamustafa and Ülker, 2020). Our findings confirm this. A large number of customers found the price of food in robotic restaurants to be low, reasonable, and value for the money. Moreover, the portion size was also found convenient when compared with the price. Customers commented specifically that:

It's reasonably priced and the portions were good [C25].

$[\ldots]$ this place is good value for the money [...] [C239].

[...] a generous, tasty, and healthy meal at a more than reasonable price [...] [C119].

4.5.2 Gastronomic aspects. As a sub-theme of food-related attributes, the gastronomic aspects consist of taste, harmony, freshness, and menu diversity. The customers' words related to the gastronomic aspects emerged as "tasty," "delicious," "yummy," "super," "nice," "good," "lots of options," "various menu choices," "innovative dishes," "good quality ingredients," "rightly spiced and fresh":

[... taste is delicious [... ] they have variety of food selection [C587].

[...] the most surprising part truly was the taste! I commented to a staff member that l've never tasted this kind of (healthy) deliciousness at a quick food restaurant. The unique combination of flavours and textures will keep me coming back for more [...] [C151].

The features of gastronomic aspects such as taste, menu variety, and freshness are related to food product quality (Zhu et al., 2019), and influence customers' restaurant decisions, satisfaction, and loyalty (Jin et al., 2012; Kivela et al., 2000). Additionally, food quality may also positively affect the emotions of customers (Peng and Chen, 2015) and is one of the most significant dimensions of dining experience which has the potential to influence restaurant success (Ribeiro and Prayag, 2019). The findings confirm the results of previous studies that the gastronomic aspects created positive customer experience with the restaurant (Harrington et al., 2012) and stimulate revisit intentions (Yan et al., 2015).

\subsection{Deficiencies}

Similar to any technology, robots have disadvantages. According to the results, although most of the comments of travellers towards robotic restaurants are positive, there are also some deficiencies pointed out by customers which are related to "robotic system," "ambience related attributes" and "food related attributes."

4.6.1 Deficiencies in the robotic system. The findings revealed that most of the customers liked the robotic system. However, some of them reported that the robots were not able to serve all items in the menu, causing service failures, and were not qualified enough to replace human employees in restaurants. For instance, several customers commented that:

Robots only served dim sum [... . Other food and drinks served by humans [C97].

$[\ldots]$ but felt a bit unnecessary. The reason is [...] only [ . . ] serve the dimsum [...] While it is cool that there is a robot server, it was useless [C426].

Other instances of service failure included incorrect orders, technical errors, and not implementing the required tasks: 
[... . the robots are so much fun! They aren't really accurate so when we got there, the robot that was supposed to take us to our table, crashed into another robot and couldn't move again [...]. A human came to solve the problem. The robots come to your table with your food, but some make errors and bring food that should go to other tables [...] [C167].

Finally, customers stressed that they needed to tap the head of robots to let them know that their tasks are completed. Others pointed out that human waiters were more efficient and better than robot waiters, because robots were not able to serve without being assisted by humans. Furthermore, several customers pointed out that they prefer humans instead of robots:

Using electronic screen to place order is a not as fun as someone talking to you. I like more human touch. The ordering process takes longer time than traditional ordering [...] [C462].

And now the food is served by robot, which I think human is obviously more efficient [C111].

The findings indicate robots were not capable and qualified enough to replace human employees in restaurants, because they cannot act independently and efficiently to address customers' needs and fulfil guest experiences (Choi et al., 2019; Ivanov and Webster, 2018). That is why some hospitality firms, especially hotels, preferred not to use service robots anymore (Qiu et al., 2019). The most notable example is the Henn na hotel that turned off half of its robots because they reportedly malfunctioned and created more work for the human employees (Shead, 2019). As the inimitable feature of human employees is needed for the hospitability and service (Golubovskaya et al., 2017), the robotic service may negatively affect the customers' experience (Gursoy et al., 2019). Therefore, highquality service with robots may not be possible for hospitality firms, but simple requirements of consumers can be meet (Lee et al., 2020).

4.6.2 Deficiencies in ambience-related attributes. Although most of the customers evaluated positively the ambiance-related features, a few of them reported some deficiencies, mostly about cleanliness:

The lady's bathroom was horrible, I never went to a restaurant that the tissue rolls were not placed inside the dispenser but just on top of the toilet, and in the middle of lunch, it went of toilet paper already [C185].

Cleanliness is one of the most important attributes of ambience in restaurant experience, because it is an indicator of the first impression of customers entering the restaurants (del Chiappa et al., 2019; Jang and Namkung, 2009). Therefore, managers of robotic restaurants need to pay special attention to this element of the customer experience.

4.6.3 Deficiencies in food-related attributes. The findings show that some customers were not satisfied with the taste of food offered by robotic restaurants:

[...] we ended up absolute disappointment with this num heong noodles, tasteless and oily, not only this, but also the other food served are not warm and equally dull. The poor taste ipoh coffee ice served here is spoiling not less [C90].

The food taste is one of the gastronomic aspects of food-related attributes and is considered as an indicator of food quality in restaurants (Zhu et al., 2019). It also affects the satisfaction and loyalty of customers (Kivela et al., 2000). Therefore, although not directly connected to the robots used in the restaurant, the food taste contributes to the overall dining experience created by robotic restaurants.

\section{Conclusion and implications}

\subsection{Contribution}

This paper contributes to the body of knowledge by identifying the components of the robotic restaurant experience based on their online reviews. In total 582 reviews of 
customers who experienced 13 different robotic restaurants in 7 different countries around the world were analysed. Additionally, the paper offers a model of components of the robotic restaurant experience (Figure 1), namely, "attraction for kids," "robotic system," "memorable experience," "ambience-related attributes," "food-related attributes (economic value and gastronomic aspects)" and "deficiencies" (in the robotic system, in ambiencerelated attributes and food-related attributes). As it is mentioned in the literature review section, food-related attributes and ambiance-related attributes are not only connected to the robotic restaurant experience, but they are parts of the overall dining experience as well. The results may help restaurant managers design memorable experiences with service robots and mitigate robots' deficiencies perceived by customers.

\subsection{Theoretical implications}

The paper has several theoretical implications. First, the results reveal that the experience of the robotic restaurants is an integral concept that consists of various components, and robots are only one of them. In that sense, the robotic restaurant experience concept steps on the general restaurant experience concept (Andersson and Mossberg, 2004; Hu et al., 2009; Kim and Jang, 2019) and evolves beyond it by adding an autonomous non-human agent (a service robot) in the experience equation. The use of service robots inevitably influences on the other restaurant experience components and the overall customer experience, e.g. by creating an attraction for kids, delivering memorable experiences to customers, saving on costs and transferring these cost savings to customers through lower prices.

Second, service robots cause some inefficiencies and service delivery failures that may decrease the quality of customers' experience (Gursoy et al., 2019). Therefore, although the use of service robots in the front-of-house activities of restaurant saves on costs, these financial benefits for the restaurant might be offset by the financial and non-financial costs of service failures (compensation for complaints, negative word-of-mouth) (Ivanov and Webster, 2018). That is why, robots need to be well integrated with the other components to provide a coherent and consistent restaurant product/experience (Mosley, 2007).

Third, the findings indicate that while customers enjoyed service robots in a restaurant context, they did not perceive robots as a threat to human employees. They considered that robots were not capable enough to replace human employees to deliver high quality restaurant service. The tasks robots performed were quite basic and sometimes they were supported by humans. Hence, robots could be used as a tool to attract and entertain

Figure 1 Components of the robotic restaurant experience

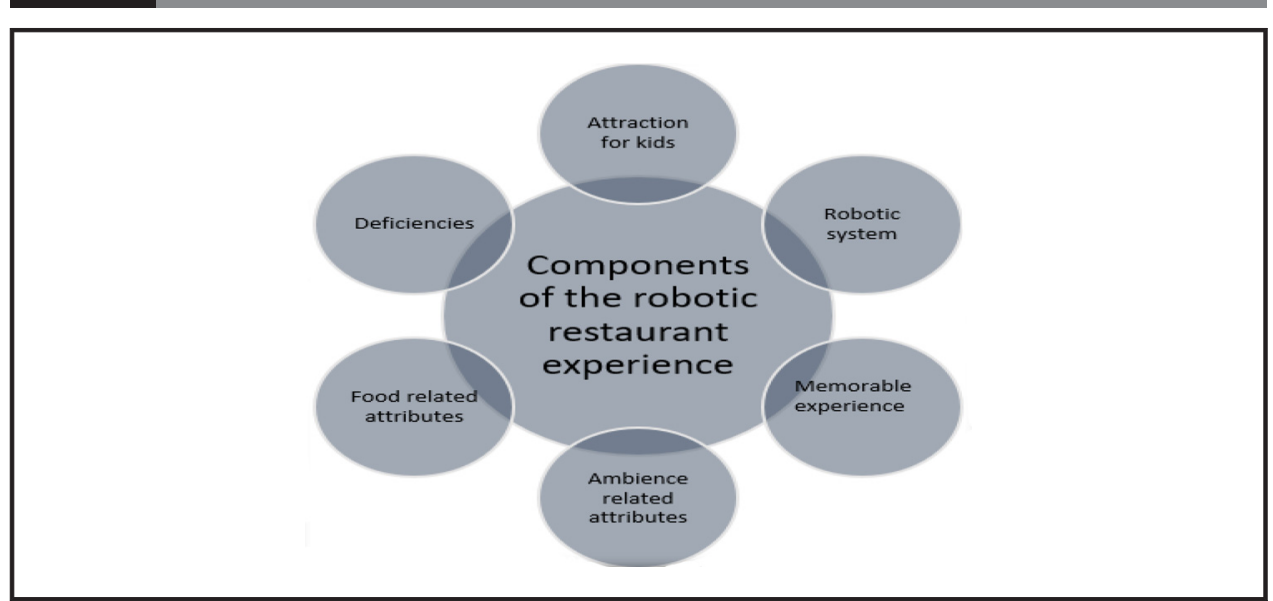


customers, rather than in replacing human employees. The current COVID-19 pandemic, however, may challenge this finding, because restaurants might be forced to look at technology, including robots, for disinfection and provision of physically distant service to protect the health of restaurant customers and employees (Seyitoğlu and Ivanov, 2020a).

Finally, the findings reconfirm the importance of food-related attributes (Ryu et al., 2012; Longart et al., 2018; Karamustafa and Ülker, 2020), ambience related attributes (Ryu and Han, 2010; Ribeiro and Prayag, 2019; Zhang et al., 2019) and memorable experience (Cao et al., 2019; Tsaur and Lo, 2020) in the restaurant experiences similar to previous studies.

\subsection{Managerial implications}

The number of robotic restaurants will increase in the future due to the advances in robotic technologies, and their decreasing prices. Demography (decreasing populations and insufficient number of born children) (Webster and Ivanov, 2020) and biosecurity threats such as COVID-19 (Zeng et al., 2020) will drive automation in the sector as well. Therefore, restaurant managers will need to consider the use of service robots in the service delivery process. In this context, this study provides important implications for restaurant managers.

First, findings clearly show that restaurant managers need to involve children in their marketing and promotional strategies. Both the results of this study and the literature support the notion that robots in restaurants enable children's enjoyment. Considering children's influence in the decision-making process in hospitality and tourism (Rhoden et al., 2016; Wu et al., 2019), including in dining out decisions (Labrecque and Ricard, 2001; Chen et al., 2016), restaurant managers can develop promotional materials that appeal to the youngest consumers and their parents. Additionally, the robots need not only to entertain the kids but also to provide opportunities for their parents to take photos and videos of their happy kids with the robots, thus further enhancing the restaurant experience of the parents.

Although most customers' comments about their robotic restaurant experience are positive, some deficiencies were also identified. The deficiencies in the robotic system relate to the inability of the robot to serve all items in the menu, service failures (e.g. incorrect orders, technical errors, forgetting the tasks and slow service), limited language capabilities, no smiles, and inability to work without human assistance, causing some customers to prefer being served human employees rather than robots. Some of these deficiencies could be easily fixed, while others may be harder to overcome. For instance, proper programming, hardware, and software upgrades can decrease or even eliminate the deficiencies related to the inability of the robot to serve all items in the menu and to the service failures, although this would probably increase the costs of the restaurant. On the other hand, the robot's dependence on human assistance cannot be overcome easily at the current technological level of service robots used in restaurants. In this regard, restaurant managers need to plan the use of service robots carefully. It would be best if the facilities of the restaurant are designed in advance with the perspective that they would be used by robots, because this would make them robot-inclusive, will facilitate the robots in implementing their tasks (Ivanov and Webster, 2017), hence decreasing their errors, and improving customers' dining experience. Furthermore, it would be wise for the managers to consider the functionalities and the appearance of the robots and adopt those that are most suitable for the tasks they need to do, although this would not necessarily mean that the robot is humanoid. For example, a humanoid robot can be used as a host inviting and entertaining guests in the restaurants, while a non-humanoid robot could be used to deliver the food.

Among the ambience-related attributes, only cleanliness was mentioned negatively by several customers. As it is one of the most significant attributes of ambience in restaurant experience (Jang and Namkung, 2009), the deficiency should be fixed by managers of robotic restaurants if they want their outlets to be competitive and profitable. Small 
autonomous cleaning robots (supported by human staff when necessary) can provide visual clues to customers about the level of hygiene in the restaurant.

Finally, our findings show that the customers' experience of robotic restaurants is shaped by non-robotic attributes such as food taste and ambience as well. Therefore, managers of robotic restaurants should not be preoccupied with service robots at the expense of the gastronomic aspects of the dining experience, for example. Robots may be novel, entertaining, attractive for kids, but if a restaurant fails to deliver its core product appropriately, it may be difficult for the robots to compensate for the restaurant's failure in the food-related attributes. Furthermore, solely adding robots to their service might not be enough for restaurants' success. It should not be forgotten that restaurants are businesses that provide food and beverage services and that the main aim of the customers visiting restaurants is to eat. In this sense, providing gastronomically valuable food and beverages that are fresh, tasty, harmonic, etc. will add value to the customers' experience. Moreover, providing food and beverages should also be economically valuable from the eyes of customers. In other words, the price and quality of food offered by restaurants should be balanced. These aspects of food quality of restaurants should be given importance by managers to enhance the customers' restaurant experience. At the end of the day, it is the customer experience that is important, not whether a restaurant is using robots or not. If robots improve customers' experiences, companies will use them; if robots make guests feel uncomfortable, companies will avoid them, similarly to Henn na hotel's decision.

\subsection{Limitation and future research directions}

This research is not without limitations. First, the sample included only 13 robotic restaurants and evaluated only the comments in the English language. There may be more robotic restaurants around the world, but due to the difficulties of reaching them, only these restaurants included in the study. Future research may use face-to-face interviews with the customers of robotic restaurants to provide richer data and more in-depth insights into customer perceptions of robotic restaurants. Since the robotic restaurants found to be attractive and entertaining for children, a study related to the children's robotic restaurant experience may be an important direction for future research. Finally, research may focus on the economic aspects of the customer experience and the employees' experience in working in robotic restaurants.

\section{References}

Ali, F., Ryu, K. and Hussain, K. (2016), "Influence of experiences on memories, satisfaction and behavioral intentions: a study of creative tourism", Journal of Travel \& Tourism Marketing, Vol. 33 No. 1, pp. 85-100.

Andersson, T.D. and Mossberg, L. (2004), "The dining experience: do restaurants satisfy customer needs?", Food Service Technology, Vol. 4 No. 4, pp. 171-177.

Antón, C., Camarero, C., Laguna, M. and Buhalis, D. (2019), "Impacts of authenticity, degree of adaptation and cultural contrast on travellers' memorable gastronomy experiences", Journal of Hospitality Marketing \& Management, Vol. 28 No. 7, pp. 743-764.

Assaker, G. (2019), "Age and gender differences in online travel reviews and user-generated-content (UGC) adoption: extending the technology acceptance model (TAM) with credibility theory", Journal of Hospitality Marketing \& Management, Vol. 29 No. 4, doi: 10.1080/19368623.2019.1653807.

Berezina, K., Ciftci, O. and Cobanoglu, C. (2019), "Robots, artificial intelligence, and service automation in restaurants", in Ivanov, S. and Webster, C. (Eds), Robots, Artificial Intelligence and Service Automation in Travel, Tourism and Hospitality, Emerald Publishing, Bingley pp. 185-219.

Bhimasta, R.A. and Kuo, P.Y. (2019), "What causes the adoption failure of service robots? A case of hennna hotel in Japan", in Adjunct Proceedings of the 2019 ACM International Joint Conference on Pervasive and Ubiquitous Computing and Proceedings of the 2019 ACM International Symposium on Wearable Computers, pp. 1107-1112, doi: 10.1145/3341162.3350843. 
Buhalis, D. and Law, R. (2008), "Progress in information technology and tourism management: 20 years on and 10 years after the internet - the state of eTourism research", Tourism Management, Vol. 29 No. 4 , pp. 609-623.

Cao, Y., Li, X.R., DiPietro, R. and So, K.K.F. (2019), "The creation of memorable dining experiences: formative index construction", International Journal of Hospitality Management, Vol. 82, pp. 308-317., doi: 10.1016/j.ijhm.2018.10.010.

Chan, A.P.H. and Tung, V.W.S. (2019), "Examining the effects of robotic service on brand experience: the moderating role of hotel segment", Journal of Travel \& Tourism Marketing, Vol. 36 No. 4, pp. 458-468.

Chen, P.T. and Hu, H.H. (2010), "How determinant attributes of service quality influence customerperceived value", International Journal of Contemporary Hospitality Management, Vol. 22 No. 4, pp. 535-551.

Chen, Y.S., Lehto, X., Behnke, C. and Tang, C.H. (2016), "Investigating children's role in family dining-out choices: evidence from a casual dining restaurant", Journal of Hospitality Marketing \& Management, Vol. 25 No. 6, pp. 706-725.

Choi, Y., Choi, M., Oh, M. and Kim, S. (2019), "Service robots in hotels: understanding the service quality perceptions of human-robot interaction", Journal of Hospitality Marketing \& Management, Vol. 29 No. 6, doi: 10.1080/19368623.2020.1703871.

Choi, J. and Zhao, J. (2010), "Factors influencing restaurant selection in South Florida: is health issue one of the factors influencing consumers' behavior when selecting a restaurant?", Journal of Foodservice Business Research, Vol. 13 No. 3, pp. 237-251.

Cohen, E. and Avieli, N. (2004), "Food in tourism: attraction and impediment", Annals of Tourism Research, Vol. 31 No. 4, pp. 755-778.

Coughlan, L.-M. and Saayman, M. (2018), "The importance of different culinary aspects when travelling the case of international tourists to South Africa", European Journal of Tourism Research, Vol. 18, pp. 95-119.

Creswell, J.W. (2009), Research Design: Qualitative, Quantitative, and Mixed Methods Approaches, Sage Publications, London.

del Chiappa, G., Atzeni, M. and Loriga, S. (2019), "Profiling airport travellers based on their perceptions, satisfaction and intention to recommend food and beverage services", European Journal of Tourism Research, Vol. 23, pp. 172-190.

Di-Clemente, E., Hernández-Mogollón, J.M. and Campón-Cerro, A.M. (2019), "Tourists' involvement and memorable food-based experiences as new determinants of behavioural intentions towards typical products", Current Issues in Tourism, Vol. 23 No. 18, doi: 10.1080/13683500.2019.1631265.

Drexler, N. and Lapré, V.B. (2019), "For better or for worse: shaping the hospitality industry through robotics and artificial intelligence", Research in Hospitality Management, Vol. 9 No. 2, pp. 117-120.

Eksiri, A. and Kimura, T. (2015), "Restaurant service robots development in Thailand and their real environment evaluation", Journal of Robotics and Mechatronics, Vol. 27 No. 1, pp. 91-102.

Elo, S., Kääriäinen, M., Kanste, O., Pölkki, T., Utriainen, K. and Kyngäs, H. (2014), "Qualitative content analysis: a focus on trustworthiness", SAGE Open, Vol. 4 No. 1, doi: 10.1177/2158244014522633.

Gentile, C., Spiller, N. and Noci, G. (2007), "How to sustain the customer experience: an overview of experience components that co-create value with the customer", European Management Journal, Vol. 25 No. 5, pp. 395-410

Glaser, B. and Strauss, A. (1967), The Discovery of Grounded Theory, Weidenfield \& Nicolson, London.

Golubovskaya, M., Robinson, N. and Solnet, D. (2017), "The meaning of hospitality: do employees understand?", International Journal of Contemporary Hospitality Management, Vol. 29 No. 5, pp. $1282-1304$.

Gursoy, D., Chi, O.H., Lu, L. and Nunkoo, R. (2019), "Consumers acceptance of artificially intelligent (Al) device use in service delivery", International Journal of Information Management, Vol. 49, pp. 157-169.

Harrington, R.J., Ottenbacher, M.C., Staggs, A. and Powell, F.A. (2012), "Generation Y consumers: key restaurant attributes affecting positive and negative experiences", Journal of Hospitality \& Tourism Research, Vol. 36 No. 4, pp. 431-449. 
Helkkula, A. (2011), "Characterising the concept of service experience", Journal of Service Management, Vol. 22 No. 3, pp. 367-389.

Heung, V.C. and Gu, T. (2012), "Influence of restaurant atmospherics on patron satisfaction and behavioral intentions", International Journal of Hospitality Management, Vol. 31 No. 4, pp. 1167-1177.

Hu, M.L.M., Chen, T.K. and Ou, T.L. (2009), "An importance-performance model of restaurant dining experience", Advances in Hospitality and Leisure, Vol. 5, pp. 207-222.

Ingerson, S. and Kim, A.K. (2016), "Exploring the value of an ethnic restaurant experience: a consumer perspective towards korean restaurants", Tourism Recreation Research, Vol. 41 No. 2 , pp. 199-212.

International Organization for Standardization (2012), "ISO 8373:2012(en) robots and robotic devices vocabulary", available at: www.iso.org/obp/ui/\#iso:std:iso:8373:ed-2:v1:en:term:2.2 (accessed 2 February 2017).

Ivanov, S. and Webster, C. (Eds) (2019c), Robots, Artificial Intelligence and Service Automation in Travel, Tourism and Hospitality, Emerald Publishing, Bingley.

Ivanov, S. and Webster, C. (2017), "Designing robot-friendly hospitality facilities", Proceedings of the Scientific Conference "Tourism. Innovations. Strategies", 13-14 October 2017, Bourgas, Bulgaria, pp. 74-81.

Ivanov, S. and Webster, C. (2018), "Adoption of robots, artificial intelligence and service automation by travel, tourism and hospitality companies - a cost-benefit analysis", in Marinov, V., Vodenska, M., Assenova, M. and Dogramadjieva E. (Eds), Traditions and Innovations in Contemporary Tourism, Cambridge Scholars Publishing, pp. 190-203.

Ivanov, S. and Webster, C. (2019b), "What should robots do? A comparative analysis of industry professionals, educators and tourists", in Pesonen, J. and Neidhardt, J. (Eds), Information and Communication Technologies in Tourism 2019, Springer, Cham, pp. 249-262.

Ivanov, S.H., Webster, C. and Berezina, K. (2017), "Adoption of robots and service automation by tourism and hospitality companies", Revista Turismo \& Desenvolvimento, Vols 27/28, pp. 1501-1517.

Ivanov, S. and Webster, C. (2019a), "Perceived appropriateness and intention to use service robots in tourism", in Pesonen, J. and Neidhardt, J. (Eds), Information and Communication Technologies in Tourism 2019, Springer, Cham, pp. 237-248, Proceedings of the International Conference in Nicosia, Cyprus, 30.01-01.02.2019.

Ivanov, S., Gretzel, U., Berezina, K., Sigala, M. and Webster, C. (2019), "Progress on robotics in hospitality and tourism: a review of the literature", Journal of Hospitality and Tourism Technology, Vol. 10 No. 4, pp. 489-521.

Jang, S. and Namkung, Y. (2009), "Perceived quality, emotions, and behavioral intentions: application of an extended Mehrabian - Russell model to restaurants", Journal of Business Research, Vol. 62 No. 4, pp. 451-460.

Jeacle, I. and Carter, C. (2011), "In TripAdvisor we trust: rankings, calculative regimes and abstract systems", Accounting, Organizations and Society, Vol. 36 Nos 4/5, pp. 293-309.

Jeong, E. and Jang, S.S. (2011), "Restaurant experiences triggering positive electronic word-of-mouth (eWOM) motivations", International Journal of Hospitality Management, Vol. 30 No. 2, pp. 356-366.

Jin, N., Lee, S. and Huffman, L. (2012), "Impact of restaurant experience on brand image and customer loyalty: moderating role of dining motivation", Journal of Travel \& Tourism Marketing, Vol. 29 No. 6, pp. 532-551.

Jin, N., Line, N.D. and Ann, S.H. (2015), "The full-service dining experience: an assessment of the generation-specific determinants of customer loyalty", Journal of Foodservice Business Research, Vol. 18 No. 4, pp. 307-327.

Karamustafa, K. and Ülker, P. (2020), "Impact of tangible and intangible restaurant attributes on overall experience: a consumer oriented approach", Journal of Hospitality Marketing \& Management, Vol. 29 No. 4, pp. 404-427.

Kazandzhieva, V. and Filipova, H. (2019), "Customer attitudes toward robots in travel, tourism, and hospitality: a conceptual framework", Robots, Artificial Intelligence, and Service Automation in Travel, Tourism and Hospitality, Emerald Publishing Limited, pp. 79-92, doi: 10.1108/978-1-78756-687320191004. 
Kim, S.S., Choi, S., Agrusa, J., Wang, K.-C. and Kim, Y. (2010), "The role of family decision makers in festival tourism”, International Journal of Hospitality Management, Vol. 29 No. 2, pp. 308-318.

Kim, D. and Jang, S.S. (2019), "The psychological and motivational aspects of restaurant experience sharing behavior on social networking sites", Service Business, Vol. 13 No. 1, pp. 25-49.

Kim, W.G. and Moon, Y.J. (2009), "Customers' cognitive, emotional, and actionable response to the servicescape: a test of the moderating effect of the restaurant type", International Journal of Hospitality Management, Vol. 28 No. 1, pp. 144-156.

Kim, J.H., Ritchie, J.B. and McCormick, B. (2012), "Development of a scale to measure memorable tourism experiences", Journal of Travel Research, Vol. 51 No. 1, pp. 12-25.

Kim, O.Y., Seo, S. and Nurhidayati, V.A. (2019), "Scale to measure tourist value of destination restaurant service", International Journal of Contemporary Hospitality Management, Vol. 31 No. 7 , pp. 2827-2844.

Kivela, J., Inbakaran, R. and Reece, J. (2000), "Consumer research in the restaurant environment. Part 3: analysis, findings and conclusions", International Journal of Contemporary Hospitality Management, Vol. 12 No. 1, pp. 13-30.

Kwun, D.J.-W. and Oh, H. (2006), "Past experience and self-image in fine dining intentions", Journal of Foodservice Business Research, Vol. 9 No. 4, pp. 3-23.

Labrecque, J. and Ricard, L. (2001), "Children's influence on family decision-making: a restaurant study", Journal of Business Research, Vol. 54 No. 2, pp. 173-176.

Lee, W.J., Kwag, S.I. and Ko, Y.D. (2020), "Optimal capacity and operation design of a robot logistics system for the hotel industry", Tourism Management, Vol. 76, p. 103971.

Lee, W.H., Lin, C.W. and Shih, K.H. (2018), "A technology acceptance model for the perception of restaurant service robots for trust, interactivity, and output quality", International Journal of Mobile Communications, Vol. 16 No. 4, pp. 361-376.

Li, J.J., Bonn, M.A. and Ye, B.H. (2019), "Hotel employee's artificial intelligence and robotics awareness and its impact on turnover intention: the moderating roles of perceived organizational support and competitive psychological climate", Tourism Management, Vol. 73, pp. 172-181.

Longart, P., Wickens, E. and Bakir, A. (2018), "An investigation into restaurant attributes: a basis for a typology", International Journal of Hospitality \& Tourism Administration, Vol. 19 No. 1, pp. 95-123.

Lu, L., Cai, R. and Gursoy, D. (2019), "Developing and validating a service robot integration willingness scale", International Journal of Hospitality Management, Vol. 80, pp. 36-51.

Mathath, A. and Fernando, Y. (2017), "Robotic transformation and its business applications in food industry", In Robotics, Automation, and Control in Industrial and Service Settings, IGI Global, pp. 281-305.

Miller, M.R. and Miller, R. (2017), Robots and Robotics: Principles, Systems, and Industrial Applications, McGraw-Hill Education.

Mosley, R.W. (2007), "Customer experience, organisational culture and the employer brand", Journal of Brand Management, Vol. 15 No. 2, pp. 123-134.

Murphy, J., Gretzel, U. and Pesonen, J. (2019), "Marketing robot services in hospitality and tourism: the role of anthropomorphism", Journal of Travel \& Tourism Marketing, Vol. 36 No. 7, pp. 784-795.

Murphy, J., Hofacker, C. and Gretzel, U. (2017), "Dawning of the age of robots in hospitality and tourism: challenges for teaching and research", European Journal of Tourism Research, Vol. 15, pp. 104-111.

Namkung, Y. and Jang, S. (2007), "Does food quality really matter in restaurants? Its impact on customer satisfaction and behavioral intentions", Journal of Hospitality \& Tourism Research, Vol. 31 No. 3, pp. 387-409.

Narangajavana Kaosiri, Y., Callarisa Fiol, L.J., Moliner Tena, M.A., Rodriguez Artola, R.M. and Sanchez Garcia, J. (2019), "User-Generated content sources in social media: a new approach to explore tourist satisfaction", Journal of Travel Research, Vol. 58 No. 2, pp. 253-265.

Nemeschansky, B. (2020), "Listen to your customer-how to manage your restaurant more effectively", Journal of Foodservice Business Research, Vol. 23 No. 1, pp. 17-45.

Oh, D., Yoo, M.M. and Lee, Y. (2019), "A holistic view of the service experience at coffee franchises: a cross-cultural study", International Journal of Hospitality Management, Vol. 82, pp. 68-81. 
Pantelidis, I.S. (2010), "Electronic meal experience: a content analysis of online restaurant comments", Cornell Hospitality Quarterly, Vol. 51 No. 4, pp. 483-491.

Peng, N. and Chen, A.H. (2015), "Diners' loyalty toward luxury restaurants: the moderating role of product knowledge", Marketing Intelligence \& Planning, Vol. 33 No. 2, pp. 179-196.

Qiu, H., Li, M., Shu, B. and Bai, B. (2019), "Enhancing hospitality experience with service robots: the mediating role of rapport building", Journal of Hospitality Marketing \& Management, pp. 1-22., doi: 10.1080/19368623.2019.1645073.

Rhoden, S., Hunter-Jones, P. and Miller, A. (2016), "Tourism experiences through the eyes of a child", Annals of Leisure Research, Vol. 19 No. 4, pp. 424-443.

Ribeiro, M.A. and Prayag, G. (2019), "Perceived quality and service experience: mediating effects of positive and negative emotions", Journal of Hospitality Marketing \& Management, Vol. 28 No. 3, pp. 285-305.

Russell, S.J. and Norvig, P. (2016), Artificial Intelligence: A Modern Approach, Pearson Education Limited, Harlow.

Ryu, K. and Han, H. (2010), "Influence of the quality of food, service, and physical environment on customer satisfaction and behavioral intention in quick-casual restaurants: moderating role of perceived price", Journal of Hospitality \& Tourism Research, Vol. 34 No. 3, pp. 310-329.

Ryu, K. and Han, H. (2011), "New or repeat customers: how does physical environment influence their restaurant experience?", International Journal of Hospitality Management, Vol. 30 No. 3, pp. 599-611.

Ryu, K. and Jang, S. (2008), "DINESCAPE: a scale for customers' perception of dining environments", Journal of Foodservice Business Research, Vol. 11 No. 1, pp. 2-22.

Ryu, K., Lee, H.R. and Kim, W.G. (2012), "The influence of the quality of the physical environment, food, and service on restaurant image, customer perceived value, customer satisfaction, and behavioral intentions", International Journal of Contemporary Hospitality Management, Vol. 24 No. 2, pp. 200-223.

Seyitoğlu, F. (2020), "Tourists' perceptions of the tour guides: the case of gastronomic tours in Istanbul", Anatolia, Vol. 31 No. 3, pp. 393-405.

Seyitoğlu, F. and Ivanov, S. (2020a), "Service robots as a tool for physical distancing in tourism", Current Issues in Tourism, (in press), doi: 10.1080/13683500.2020.1774518.

Seyitoğlu, F. and Ivanov, S. (2020b), "A conceptual study of the strategic role of gastronomy in tourism destinations", International Journal of Gastronomy and Food Science, Vol. 21, p. 100230, doi: 10.1016/j. ijgfs.2020.100230.

Shead, S. (2019), "World's first robot hotel fires half of its robots", Forbes, available at: www.forbes.com/ sites/samshead/2019/01/16/worlds-first-robot-hotel-fires-half-of-its-robots/\#78bf9dfde1b1

Stepchenkova, S., Kirilenko, A.P. and Morrison, A.M. (2009), "Facilitating content analysis in tourism research", Journal of Travel Research, Vol. 47 No. 4, pp. 454-469.

Sthapit, E. (2017), "Exploring tourists' memorable food experiences: a study of visitors to Santa's official hometown", Anatolia, Vol. 28 No. 3, pp. 404-421.

Thomas, D.R. (2006), "A general inductive approach for analyzing qualitative evaluation data", American Journal of Evaluation, Vol. 27 No. 2, pp. 237-246.

Tsaur, S.H. and Lo, P.C. (2020), "Measuring memorable dining experiences and related emotions in fine dining restaurants", Journal of Hospitality Marketing \& Management, pp. 1-24, doi: 10.1080/ 19368623.2020.1748157.

Tung, V.W.S. and Au, N. (2018), "Exploring customer experiences with robotics in hospitality", International Journal of Contemporary Hospitality Management, Vol. 30 No. 7, pp. 2680-2697.

Tung, V.W.S. and Law, R. (2017), "The potential for tourism and hospitality experience research in human-robot interactions", International Journal of Contemporary Hospitality Management, Vol. 29 No. 10, pp. 2498-2513.

Tuomi, A., Tussyadiah, I. and Stienmetz, J. (2019), "Service robots and the changing roles of employees in restaurants: a cross cultural study", e-Review of Tourism Research, Vol. 17 No. 5, pp. 662-673. 
Tussyadiah, I. (2020), "A review of research into automation in tourism: launching the annals of tourism research curated collection on artificial intelligence and robotics in tourism", Annals of Tourism Research, Vol. 81, doi: 10.1016/j.annals.2020.102883.

Vu, H.Q., Li, G., Law, R. and Zhang, Y. (2019), "Exploring tourist dining preferences based on restaurant reviews", Journal of Travel Research, Vol. 58 No. 1, pp. 149-167.

Webster, C. and Ivanov, S. (2020), "Demographic change as a driver for tourism automation", Journal of Tourism Futures, doi: 10.1108/JTF-10-2019-0109.

Wu, M.Y., Wall, G., Zu, Y. and Ying, T. (2019), "Chinese children's family tourism experiences", Tourism Management Perspectives, Vol. 29, pp. 166-175.

Xiao, L. and Kumar, V. (2019), "Robotics for customer service: a useful complement or an ultimate substitute?", Journal of Service Research, doi: 10.1177/1094670519878881.

Yan, X., Wang, J. and Chau, M. (2015), "Customer revisit intention to restaurants: evidence from online reviews", Information Systems Frontiers, Vol. 17 No. 3, pp. 645-657.

Yoo, K.H. and Gretzel, U. (2011), "Influence of personality on travel-related consumer-generated media creation", Computers in Human Behavior, Vol. 27 No. 2, pp. 609-621.

Yrjölä, M., Rintamäki, T., Saarijärvi, H., Joensuu, J. and Kulkarni, G. (2019), "A customer value perspective to service experiences in restaurants", Journal of Retailing and Consumer Services, Vol. 51, pp. 91-101.

Yu, C.E. (2020), "Humanlike robots as employees in the hotel industry: thematic content analysis of online reviews", Journal of Hospitality Marketing \& Management, Vol. 29 No. 1, pp. $22-38$.

Yu, C.E. and Ngan, H.F.B. (2019), "The power of head tilts: gender and cultural differences of perceived human vs human-like robot smile in service", Tourism Review, Vol. 74 No. 3, pp. 428-442.

Zeng, Z., Chen, P.J. and Lew, A.A. (2020), "From high-touch to high-tech: COVID-19 drives robotics adoption", Tourism Geographies, pp. 1-11.

Zhang, M., Kim, P.B. and Goodsir, W. (2019), "Effects of service experience attributes on customer attitudes and behaviours: the case of New Zealand café industry", Journal of Hospitality Marketing \& Management, Vol. 28 No. 1, pp. 28-50.

Zhang, H., Wu, Y. and Buhalis, D. (2018), "A model of perceived image, memorable tourism experiences and revisit intention”, Journal of Destination Marketing \& Management, Vol. 8, pp. 326-336.

Zhong, L., Sun, S., Law, R. and Zhang, X. (2020), "Impact of robot hotel service on consumers' purchase intention: a control experiment", Asia Pacific Journal of Tourism Research, Vol. 25 No. 7, pp. 780-798.

Zhu, D.H., Zhang, Z.J., Chang, Y.P. and Liang, S. (2019), "Good discounts earn good reviews in return? Effects of price promotion on online restaurant reviews", International Journal of Hospitality Management, Vol. 77, pp. 178-186.

\section{Further reading}

Merriam-Webster (2020), available at: https://learnersdictionary.com/ (accessed 08 February 2020).

\section{About the authors}

Faruk Seyitoğlu (PhD) currently works as an Assistant Professor at Mardin Artuklu University Faculty of Tourism. His research interests are tourist motivations and experiences, destination management, destination marketing, gastronomy and food studies, tourism and gastronomy education, robots and robotic technology in tourism/hospitality services. Faruk Seyitoğlu is the corresponding author and can be contacted at: seyitoglu.f@gmail.com

Stanislav Ivanov is currently Professor and Vice Rector (Research) at Varna University of Management, Bulgaria (www.vum.bg) and CEO of the consuliting company Zangador Ltd. (www.zangador.eu). Prof. Ivanov is the Founder and Editor-in-chief of the European Journal of Tourism Research (http://ejtr.vumk.eu) and serves in the Editorial boards of over 30 other journals. His research interests include robonomics, robots in tourism/hospitality, the economics of technology, revenue management, destination marketing, tourism and 
economic growth, political issues in tourism, etc. His publications have appeared in different academic journals - Annals of Tourism Research, Tourism Management, Tourism Management Perspectives, International Journal of Revenue Management, Tourism Economics, Journal of Destination Marketing \& Management, Journal of Heritage Tourism, Tourism Today, Tourism, Tourism and Hospitality Research, Tourism Planning and Development, International Journal of Hospitality and Tourism Administration, Technology in Society, Journal of Economic Studies, Journal of Southern Europe and the Balkans, South-Eastern Europe Journal of Economics and other journals. For more information about Prof. Ivanov please visit his personal website: www.stanislavivanov.com

For instructions on how to order reprints of this article, please visit our website: www.emeraldgrouppublishing.com/licensing/reprints.htm

Or contact us for further details: permissions@emeraldinsight.com 